Original Research

\title{
High Energy Density Rechargeable Aqueous Lithium Batteries with an Aqueous Hydroquinone Sulfonic Acid and Benzoquinone Sulfonic Acid Redox Couple Cathode
}

Hironori Takagi, Koichi Kakimoto, Daisuke Mori, Sou Taminato, Yasuo Takeda, Osamu Yamamoto *, Nobuyuki Imanishi

Graduate School of Engineering, Mie University, Tsu, Mie, 514-8507, Japan; E-Mails: 419m335@m.mie-u.ac.jp; 420m314@m.mie-u.ac,jp; daisuke.mori@chem.mie-u.ac.jp; taminato@chem.mie-u.ac.jp; takeda@chem.mie-u.ac.jp; yamamoto@chem.mie-u.ac.jp; imanishi@chem.mie-u.ac.jp

* Correspondence: Osamu Yamamoto; E-Mail: yamamoto@chem.mie-u.ac.jp

Academic Editor: Ahamed Irshad

Special Issue: Batteries: Past, Present and Future

Journal of Energy and Power Technology

2021, volume 3 , issue 1

doi:10.21926/jept.2101010
Received: January 12, 2021

Accepted: February 12, 2021

Published: February 24, 2021

\begin{abstract}
The demand for high energy density rechargeable batteries beyond lithium-ion batteries has increased for electric vehicles. In the present study, a novel high energy density rechargeable aqueous lithium battery was proposed. The battery was composed of a lithium metal anode, a lithium-stable non-aqueous electrolyte, a water-stable lithium-ion conducting solid electrolyte of $\mathrm{Li}_{1.4} \mathrm{Al}_{0.4} \mathrm{Ge}_{0.2} \mathrm{Ti}_{1.4}\left(\mathrm{PO}_{4}\right)_{3}$-epoxy- $\mathrm{TiO}_{2}$ separator, and a hydroquinone sulfonic acid (HQS)/benzoquinone sulfonic acid (BQS) redox couple in an aqueous acetic acid solution (HAc). An open-circuit voltage of $3.7 \mathrm{~V}$ at $25^{\circ} \mathrm{C}$ was recorded, and the theoretical energy density of the battery based on the reaction $2 \mathrm{Li}+\mathrm{BQS}+2 \mathrm{H}_{2} \mathrm{O}=2$ $\mathrm{LiOH}+\mathrm{HQS}$ was $833 \mathrm{Whkg}^{-1}$, about two times higher than that of the lithium-ion battery. The battery was successfully cycled at $0.5 \mathrm{~mA} \mathrm{~cm}^{-2}$ and $25^{\circ} \mathrm{C}$ with low polarization.
\end{abstract}

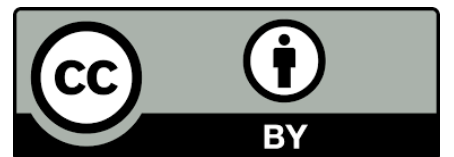

(C) 2021 by the author. This is an open access article distributed under the conditions of the Creative Commons by Attribution License, which permits unrestricted use, distribution, and reproduction in any medium or format, provided the original work is correctly cited. 


\section{Keywords}

High energy density battery; aqueous lithium battery; lithium metal electrode; benzoquinone sulfonic acid; solid electrolyte

\section{Introduction}

A lithium anode is the best candidate for a high energy density battery because of its high theoretical specific capacity of $3860 \mathrm{mAhg}^{-1}$ and highest electrochemical reduction potential of $3.04 \mathrm{~V}$ in comparison to a normal hydrogen electrode (NHE). Lithium reacts vigorously with water; therefore, an aqueous electrolyte is never used, and non-aqueous electrolytes were mainly developed for batteries with lithium anodes [1, 2]. In 2004, Visco et al. [3, 4] proposed a unique aqueous lithium-air battery that consisted of a lithium metal anode, a water-stable lithium-ion conducting solid electrolyte separator, an aqueous electrolyte, and an air electrode. The electrolyte separator of NASICON-type $\mathrm{Li}_{1+x} \mathrm{Al}_{x} \mathrm{Ti}_{2-x}\left(\mathrm{PO}_{4}\right)_{3}$ (LATP) prevented direct contact between the lithium metal anode and the aqueous electrolyte solution. The aqueous lithium-air battery has been expected to give a high power density and to operate in an air atmosphere [5].

Mainly, two types of aqueous lithium batteries have been proposed in the literature; the one with an aqueous electrolyte and water-stable lithium intercalation electrodes [6], and the other with a water-stable solid electrolyte separator [3]. The former aqueous lithium battery exhibits a high power density; however, the specific energy density is lower than that of conventional lithium-ion batteries [7]. At present, various aqueous lithium batteries with solid electrolyte separators have been suggested. Zhou and co-workers reported a prototype aqueous lithium battery with a solid electrolyte separator [8]. This cell was assembled using $1 \mathrm{M} \mathrm{LiClO}_{4}$ in ethylene carbonate and dimethyl carbonate as an electrolyte for the $\mathrm{Li}$ anode and an aqueous solution containing $1 \mathrm{M} \mathrm{LiOH}$ and $1 \mathrm{M} \mathrm{KOH}$ as the electrolytes for the $\mathrm{Ni}(\mathrm{OH})_{2}$ cathode. The two electrolytes were separated by the LATP. The energy density of this cell was calculated as $857 \mathrm{Whkg}^{-1}$ based on the weights of the electrode active materials. Similarly, a cell consisting of a lithium anode with a liquid electrolyte and water-soluble $\mathrm{Fe}(\mathrm{CN})_{6}{ }^{3-} / \mathrm{Fe}(\mathrm{CN})_{6}{ }^{4-}$ redox couple cathode separated by LATP was proposed by Goodenough et al. [9]. The theoretical specific energy density of this redox couple was recorded as $392 \mathrm{Whkg}^{-1}$, comparable to that of conventional lithium-ion batteries, although a higher power density was expected. Wu et al. reported a Li/gel-polymer electrolyte/LATP/aqueous electrolyte/ $\mathrm{LiMn}_{2} \mathrm{O}_{4}$ cell [10]. The specific energy density of the $\mathrm{Li} / \mathrm{LiMn}_{2} \mathrm{O}_{4}$ cell based on the mass of the electrodes was estimated to be $446 \mathrm{Whkg}^{-1}$. Imanishi and co-workers [11-13] proposed a higher specific energy density aqueous lithium battery that consisted of a lithium anode with a liquid electrolyte, an aqueous $\mathrm{MCl}_{2}(\mathrm{M}=\mathrm{Co}, \mathrm{Ni}$, and $\mathrm{Sn}$ ) solution catholyte, and a $\mathrm{Li}_{1.4} \mathrm{Al}_{0.4} \mathrm{Ge}_{0.2} \mathrm{Ti}_{1.4}\left(\mathrm{PO}_{4}\right)_{3}$ (LAGTP) separator. The theoretical specific energy density of the $\mathrm{Li} / \mathrm{NiCl}_{2}$ cell was as high as $1047 \mathrm{Whkg}^{-1}$ based on the weights of lithium and $\mathrm{NiCl}_{2}$ and was at least twice of the conventional lithium-ion battery. The estimated specific energy density calculated using the mass of cell components with a $0.1 \mathrm{~mm}$ thick LAGTP separator (except packaging) was $670 \mathrm{Whkg}^{-1}$. Moreover, it has been shown in the literature that the battery with a liquid-type catholyte could be developed into a large scale battery without the degradation in cell performance due to the high diffusibility of the active material in the catholyte [13]. 
In this study, we have developed a novel aqueous lithium rechargeable battery with a watersoluble organic redox couple catholyte of 1,2-hydroquinone-3-sulfonic acid (HQS) and 1,2benzoquinone-3-sulfonic acid (BQS) and a lithium metal anode. Feng et al. [14] reported an organic cathode composed of 3,4,9,10-perylene-tetracarboxylic acid-dianhydride in an organic solvent, but the solubility of this compound in water was very low. Also, the catholyte and lithium metal anode were separated by LAGTP. The benzoquinone-hydroquinone couple is the prototypical example of an organic redox system, and their electrochemical behavior has been extensively studied for the past many years [15-17]. However, the solubility of benzoquinone in water is not very high. Narayanan et al. [18-20] reported an aqueous flow battery based on a water-soluble organic redox couple of 1,2-benzoquinone-3,5-disulfonic acid at the cathode and anthraquinone-2-sulfonic acid at the anode. A water-soluble aqueous solution of BQS/HQS was used as the catholyte. The cell reaction of the battery was the following;

$$
2 \mathrm{Li}+\mathrm{BQS}+2 \mathrm{H} 2 \mathrm{O}=2 \mathrm{LiOH}+\mathrm{HQS}
$$

The open-circuit voltage (OCV) of the cell was around $3.7 \mathrm{~V}$ at $25^{\circ} \mathrm{C}$. The theoretical specific energy density based on the masses of the lithium anode, $\mathrm{H}_{2} \mathrm{O}$, and $\mathrm{BQS}$ with an OCV of 3.7 $\mathrm{V}$ was $833 \mathrm{Whkg}^{-1}$. The quinones are comparatively cheaper $\left(\sim \$ 5-10 \mathrm{~kg}^{-1}\right)$ [18]; hence are highly appropriate and attractive for large-size batteries for electric vehicles and various electrical energy storage applications.

\section{Experimental}

HQS was prepared by ion exchange of 1, 2-hydroquinone-3-sulfonic potassium salt (HQSK, Alfa Aesar) using an ion-exchange resin Amerlyst 15 DRY (Kurita Water, Japan). Since LAGTP had to be decomposed in a strongly acidic solution [21], the $\mathrm{pH}$ of the catholyte was adjusted to $\mathrm{pH} 2$. The aqueous solutions of $0.8 \mathrm{M} \mathrm{HQS}$ in $5.5 \mathrm{M} \mathrm{HAc}$ and $2 \mathrm{M} \mathrm{LiCl}, 0.015 \mathrm{M} \mathrm{H}_{2} \mathrm{SO}_{4}$, and $10 \mathrm{~m} \mathrm{1-butyl-3-}$ methylimidazolium chloride (IBMmCl) with $1.0 \mathrm{M} \mathrm{HCl}$ (Sigma-Aldrich), all at $\mathrm{pH} 2.0$, were examined as the catholyte. The $2 \mathrm{M} \mathrm{LiCl}$ was added to the $5.5 \mathrm{M} \mathrm{HAc}$ to increase the conductivity of the electrolyte. The electrochemical performance of the HQS/BQS redox reaction was studied using a beaker cell with a working electrode consisting of a mixture of a Pt-loaded carbon electrode (Pt-C) (Tanaka Kikinzoku, Japan) and polytetrafluoroethylene (PTFE) (Daikin Japan) (8:2 weight ratio), a Pt counter electrode, and $\mathrm{Ag} / \mathrm{AgCl}$ in saturated $\mathrm{KCl}$ reference electrode. The cathode mixture was pressed on a titanium mesh (Nikara, Japan).

The schematic diagram of an in-house-built Swagelok-type full test cell is shown in Figure 1 . The cell consisted of a $200 \mu \mathrm{m}$ thick lithium metal anode (Honjometal, Japan), $\mathrm{Li}\left(\mathrm{CF}_{3} \mathrm{SO}_{2}\right)_{2} \mathrm{~N}$ (LiFSI) dissolved in tetra(ethylene)glycol dimethyl ether (G4) (2:1 mole ratio) and 1,3 dioxolane (DOL, 50 vol\%) as anode electrolyte, ca. $200 \mu \mathrm{m}$ thick LAGTP-epoxy-10 wt\% $\mathrm{TiO}_{2}$ as the solid electrolyte separator, an aqueous solution of 0.8M HQS in $5.5 \mathrm{M} \mathrm{HAc}$ and $2 \mathrm{M} \mathrm{LiCl}$ as the catholyte, and a mixture of Pt-C and PTFE as the cathode. The anode electrolyte LiFSI-2G4-50 vol\% DOL was reported to suppress lithium dendrite formation at a high current density [22]. LAGTP-epoxy-TiO 2 films were prepared by a previously reported tape casting method [23]. Fine LAGTP powder was prepared by a sol-gel method using citric acid [24]. Briefly, stoichiometric amounts of $\mathrm{Ti}_{(}\left(\mathrm{OC}_{2} \mathrm{H}_{5}\right)_{4}$ and $\mathrm{Ge}\left(\mathrm{OC}_{2} \mathrm{O}_{5}\right)_{4}$ (Sigma Aldrich) were dissolved in ethylene glycol, added to a $0.2 \mathrm{M}$ aqueous solution of citric acid, and the solution was stirred well. After the gel formation, stoichiometric 
amounts of $\mathrm{LiNO}_{3}, \mathrm{Al}\left(\mathrm{NO}_{3}\right) 3.9 \mathrm{H} 2 \mathrm{O}$, and $\mathrm{NH}_{4} \mathrm{H}_{2} \mathrm{PO}_{4}$ (Nakalai Tesque, Japan) were added to the gel. The gel was kept at $220^{\circ} \mathrm{C}$ for several hours and was then heated at $580{ }^{\circ} \mathrm{C}$ for $4 \mathrm{~h}$. The gel was then ground and heated again at $800{ }^{\circ} \mathrm{C}$ for $4 \mathrm{~h}$. A mixture of LAGTP, a fine $\mathrm{TiO}_{2}$ powder (Kojundo Chemicals Japan, $2 \mu \mathrm{m}$ particle size), Menhaden fish oil (Sigma Aldrich), Burver@B-98 (Sigma Aldrich), and benzyl-butyl-phthalate (Wako Chemicals, Japan) was ball-milled using a plenary mill (Fritsch, Mode 7). The obtained slurry was tape-casted onto a silicon-coated polyethylene substrate using a two doctor blade apparatus. The green tape-cast sheet was carefully dried at $4{ }^{\circ} \mathrm{C}$ followed by heating at $500{ }^{\circ} \mathrm{C}$ to remove organic additives, and finally sintered at $950{ }^{\circ} \mathrm{C}$. The LAGTP-epoxy- $\mathrm{TiO}_{2}$ films were prepared by dipping the $\mathrm{LAGTP}^{-\mathrm{TiO}_{2}}$ film into a tetrahydrofuran solution containing 0.05 M 1,3-phenylene diamine (Sigma-Aldrich) and 2,2-bis(4-glycidyloxyphenyl)propane (Sigma-Aldrich), followed by a polymerization reaction at $170{ }^{\circ} \mathrm{C}$ for $24 \mathrm{~h}$ [25]. The amount of epoxy in the LAGTP-TiO 2 film estimated from the weight change was around ca $2 \mathrm{wt} \%$. Lastly, the Pt loaded porous carbon (Tanaka Kikinzoku, Japan) and polytetrafluoroethylene (PTFE) mixture were pressed onto a titanium mesh (Nikara, Japan).

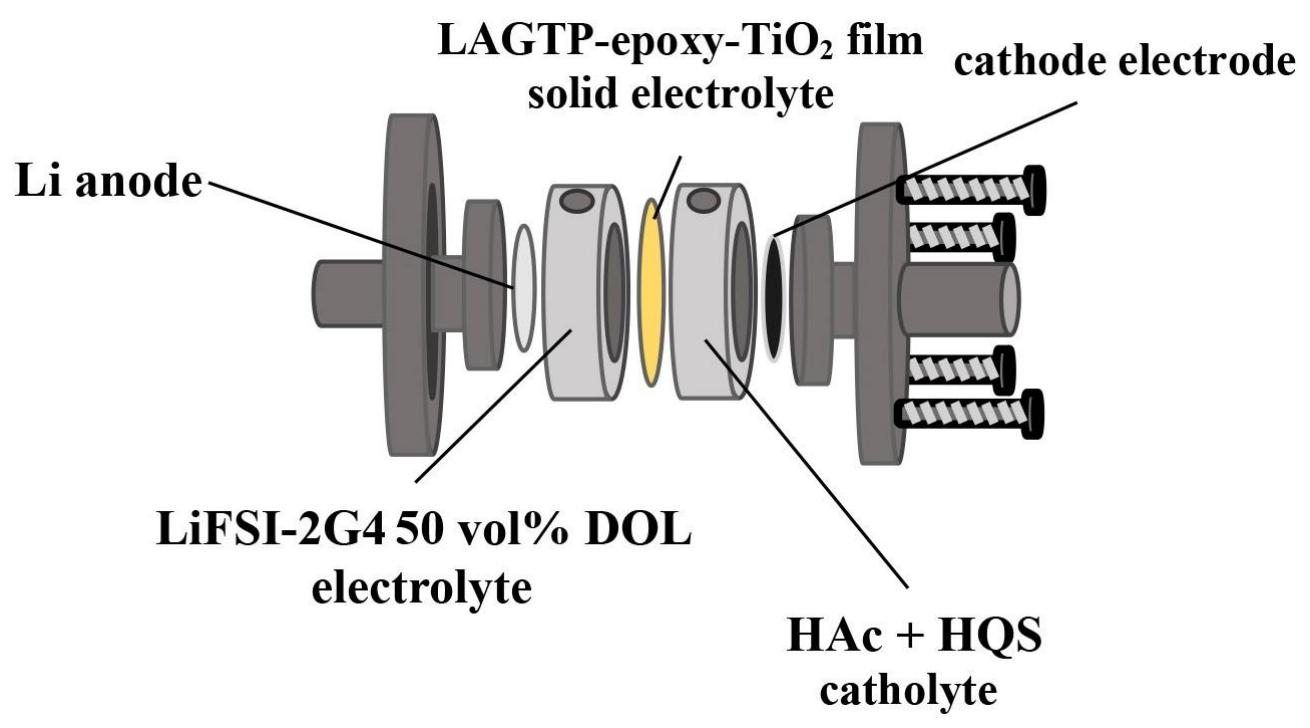

Figure 1 Schematic of the test cell.

Impedance measurements were conducted using a frequency analyzer (Solatron 1260) in the frequency range of $0.1 \mathrm{~Hz}$ to $1 \mathrm{M} \mathrm{Hz}$ at a bias voltage of $10 \mathrm{mV}$. Bulk and grain boundary conductivities of the samples were estimated from the complex impedance plots using Zview 2 software. Electrochemical measurements were conducted using a multichannel potentiogalvanostat (Bio-Logic Science Instrument VMPX).

\section{Results and Discussion}

The stability of the solid electrolyte in the aqueous catholyte is an important requirement for the separator in the aqueous lithium batteries. The stability of LATP in the aqueous electrolytes was examined by Imanishi and co-workers [21, 26-28]. They found that LATP was unstable in strong acid and alkaline aqueous solutions, and the lithium-ion conductivity of LATP was decreased considerably by its immersion in these solutions. We studied the impedance change of the tape cast LAGTP-epoxy- $\mathrm{TiO}_{2}$ films in an aqueous solution of $0.8 \mathrm{M}$ HQS in 5.5 M HAc and 2M 
$\mathrm{LiCl}(\mathrm{pH}=2.0)$. The impedance profiles of $\mathrm{Au} / \mathrm{LAGTP}-\mathrm{epoxy}-\mathrm{TiO}_{2} / \mathrm{Au}$ as a function of the immersion period in Figure 2(a) showed that the initial total conductivity of the film was $3.7 \times 10^{-4} \mathrm{Scm}^{-1}$ at $25^{\circ} \mathrm{C}$. The bulk conductivity was not changed for two weeks, but the grain boundary conductivity was decreased. The total conductivity of the electrolyte after two weeks was $1.5 \times 10^{-4} \mathrm{Scm}^{-1}$, followed by no further significant change in total conductivity. The XRD patterns of the LAGTPepoxy- $\mathrm{TiO}_{2}$ film before and after immersion in $0.8 \mathrm{M} \mathrm{HQS}$ in $5.5 \mathrm{M} \mathrm{HAc}$ and $2 \mathrm{M} \mathrm{LiCl}(\mathrm{pH}=2.0)$ for two weeks also showed no significant change. The other requirement of the solid electrolyte separator for the aqueous lithium cell is to be water impermeable. A water permeation test was conducted using an H-type cell, where one chamber was filled with pure water, and the other chamber was filled with $1 \mathrm{M} \mathrm{LiCl}$ aqueous solution [25]. The water permeation rate was determined from the $\mathrm{Cl}^{-}$content in the chamber with water. The $\mathrm{LAGTP}^{-\mathrm{TiO}_{2}}$ film without epoxy resin had a high lithium-ion conductivity of $8.9 \times 10^{-4} \mathrm{Scm}^{-1}$, but exhibited water permeation through the film, while no water diffused through the LAGTP-epoxy-TiO ${ }_{2}$ film over a period of one week. The LAGTP-epoxy-TiO 2 film was thus acceptable and recommended for the separator in the proposed aqueous lithium batteries.

(a)

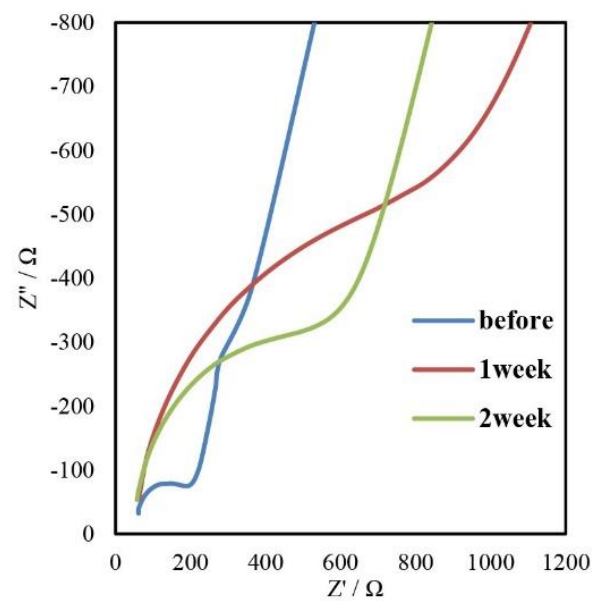

(b)

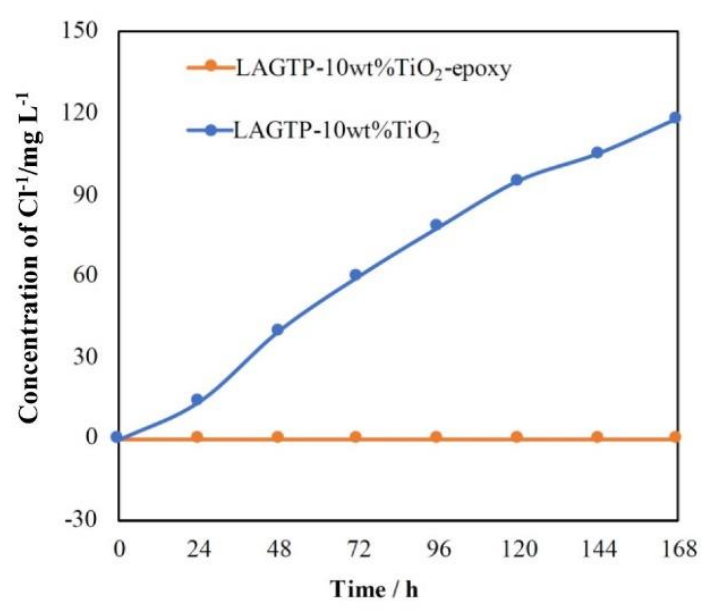

Figure 2 (a) Impedance profiles of the LAGTP epoxy- $\mathrm{TiO}_{2}$ immersed in an aqueous solution of $0.8 \mathrm{M} \mathrm{HQS}$ in $5.5 \mathrm{M} \mathrm{HAc}$ and $2 \mathrm{M} \mathrm{LiCl}$ at pH 2.0 and $25^{\circ} \mathrm{C}$ as a function of time (b) Water permeation test results for $\mathrm{LAGTP}-\mathrm{TiO}_{2}$ and $\mathrm{LAGTP}-\mathrm{epoxy}-\mathrm{TiO}_{2}$.

Figure 3 shows cyclic voltammograms (CV) for the Pt-C electrode of an aqueous solution of 0.8 $\mathrm{M} \mathrm{HQS}$ in $5.5 \mathrm{M} \mathrm{HAc}$ and $2 \mathrm{M} \mathrm{LiCl}$, an aqueous solution of $15 \mathrm{mM} \mathrm{H}_{2} \mathrm{SO}_{4}$, and $10 \mathrm{~m} \mathrm{IBMmCl}$ with $1.0 \mathrm{M} \mathrm{HCl}(\mathrm{IBMmCl}-\mathrm{HCl})$ aqueous solution at $25^{\circ} \mathrm{C}$, where $\mathrm{HQS}$ was oxidized to $\mathrm{BQS}$ at $0.5 \mathrm{~mA} \mathrm{~cm}{ }^{-2}$ for $20 \mathrm{~h}$. The imidazole supporting electrolyte of IBM-1.0 M HCl was found to suppress the Michael addition reaction of benzoquinone with water [29]. The $\mathrm{CV}$ curve of $15 \mathrm{mM} \mathrm{H}_{2} \mathrm{SO}_{4}$ solution was similar to that of $1 \mathrm{mM} \mathrm{1,} 2$ benzoquinone-3,5-disulfonic acid (BQDS) in $1 \mathrm{M} \mathrm{H}_{2} \mathrm{SO}_{4}$ solution [17]. The peak potential of $1.15 \mathrm{~V}$ vs. NHE was comparable to $1.13 \mathrm{~V}$ vs. NHE observed in the case of 1 $\mathrm{mM}$ BQDS in $1 \mathrm{M} \mathrm{H}_{2} \mathrm{SO}_{4}$ solution [18] corresponding to the redox reaction of HQDS/BQDS. The hydrogen evolution reaction and oxygen evolution potentials at $\mathrm{pH} 2.0$ without overpotential were $-0.118 \mathrm{~V}$ vs. NHE and $1.111 \mathrm{~V}$ vs. NHE, respectively. The oxygen and hydrogen evolution reactions were observed at around $1.5 \mathrm{~V}$ vs. $\mathrm{NHE}$ and $0.0 \mathrm{~V}$ vs. $\mathrm{NHE}$, respectively in $15 \mathrm{mM} \mathrm{H}_{2} \mathrm{SO}_{4}$. 
The CV for $5.5 \mathrm{M} \mathrm{HAC}$ and $2 \mathrm{M} \mathrm{LiCl}$ and $10 \mathrm{~m} \mathrm{IBMmCl}$ with $1.0 \mathrm{M} \mathrm{HCl}$ indicated the initiation of the $\mathrm{HQS}$ oxidation reaction at around $0.7 \mathrm{~V}$ vs. NHE, although no clear oxidation reaction peak was observed. The CV results for $\mathrm{HQS}$ in $15 \mathrm{mM} \mathrm{H}_{2} \mathrm{SO}_{4}$ confirmed that the HQS/BQS redox reaction proceeds by a two-electron reaction of $\mathrm{BQS}+2 \mathrm{H}^{+}+2 \mathrm{e}=\mathrm{HQS}$ as reported previously for the hydroquinone-benzoquinone redox system in an aqueous solution [30]. Wu et al. observed the electrochemical oxidation reaction of $\mathrm{HAc}$ in an aqueous solution of $0.5 \mathrm{M} \mathrm{H}_{2} \mathrm{SO}_{4}$ at $1.14 \mathrm{~V}$ vs. NHE for a $\mathrm{Pt}_{60} \mathrm{Ru}_{10} \mathrm{Sn}_{30}$ electrode with a high $\mathrm{Sn}$ content [31], while Sine et al. suggested that the electrode with a low $\mathrm{Sn}$ content in $\mathrm{Pt}_{80} \mathrm{Ru}_{10} \mathrm{Sn}_{10}$ showed no oxidation of $\mathrm{HAc}$ in $1 \mathrm{M} \mathrm{HClO}{ }_{3}-0.1 \mathrm{M}$ HAc aqueous solution [32]. The results showed in the present study were in agreement with the above studies and exhibited no clear oxidation peak for HAc.

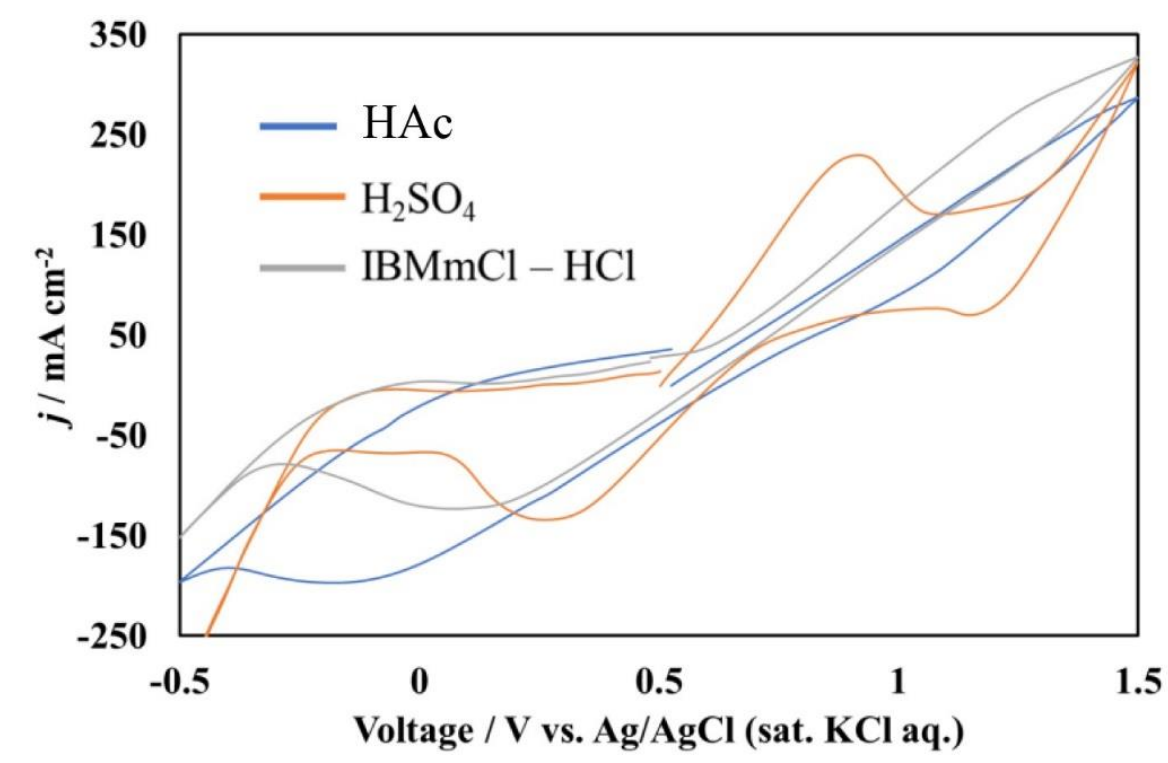

Figure 3 Cyclic voltammograms of the Pt-C electrode for $0.8 \mathrm{M}$ HQS in $5.5 \mathrm{M} \mathrm{HAc}$ and 2 $\mathrm{M} \mathrm{LiCl}(\mathrm{HAC}), 15 \mathrm{mM} \mathrm{H}_{2} \mathrm{SO}_{4}\left(\mathrm{H}_{2} \mathrm{SO}_{4}\right)$, and $10 \mathrm{~m} \mathrm{IBMmCl}-1.0 \mathrm{M} \mathrm{HCl}(\mathrm{IBMmCl}-\mathrm{HCl})$ aqueous solutions at $25^{\circ} \mathrm{C}$. The scan rate was $5 \mathrm{mV} \mathrm{s}^{-1}$.

The redox reaction kinetics of $\mathrm{HQS} / \mathrm{BQS}$ on Pt-C electrodes was examined in aqueous solutions with $\mathrm{pH} 2.0$ at $25^{\circ} \mathrm{C}$. The overpotential $(\eta)$ vs. current density $(\mathrm{j})$ curves of $0.8 \mathrm{M} \mathrm{HQS}$ in $5.5 \mathrm{M} \mathrm{HAc}-$ $2 \mathrm{M} \mathrm{LiCl}(\mathrm{HAC}), 15 \mathrm{mM} \mathrm{H}_{2} \mathrm{SO}_{4}\left(\mathrm{H}_{2} \mathrm{SO}_{4}\right)$, and $10 \mathrm{~m} \mathrm{IBMmCl}-1.0 \mathrm{M} \mathrm{HCl}$ (IBMmCl-HCl) aqueous solutions are shown in Figure 4, where the BQS reduction overpotentials were measured once around $20 \%$ of HQS was oxidized, and the overpotentials were recorded after the polarization for $10 \mathrm{~min}$ at each current density. The results showed that the oxidation overpotentials of HQS were low in the catholyte, whereas the reduction overpotentials of BQS were higher than the oxidation overpotential and depended on the catholyte. At a low current density, the lowest overpotential was observed in $0.8 \mathrm{M} \mathrm{HQS}$ taken in $5.5 \mathrm{M} \mathrm{HAc}-2 \mathrm{M} \mathrm{LiCl}$ (HAc), but at a high current density, the opposite was observed, and the overpotentials of the studied catholyte was higher than the other catholyte. The change in cell voltage with polarization period curves are shown in Figure 5 . The cells were charged initially at $0.5 \mathrm{mAcm}^{-2}$ for $10 \mathrm{mAh}$ and then discharged at $0.5 \mathrm{mAcm}^{-2}$. At this moment, around $80 \%$ of BQS was reduced to HQS with an overpotential of $0.5 \mathrm{~V}$. The flat discharge overpotentials of around $0.15 \mathrm{~V}$ at $0.5 \mathrm{mAcm}^{-2}$ were observed in $15 \mathrm{mM} \mathrm{H}_{2} \mathrm{SO}_{4}$ and 5.5 M HAc-2 M LiCl. 


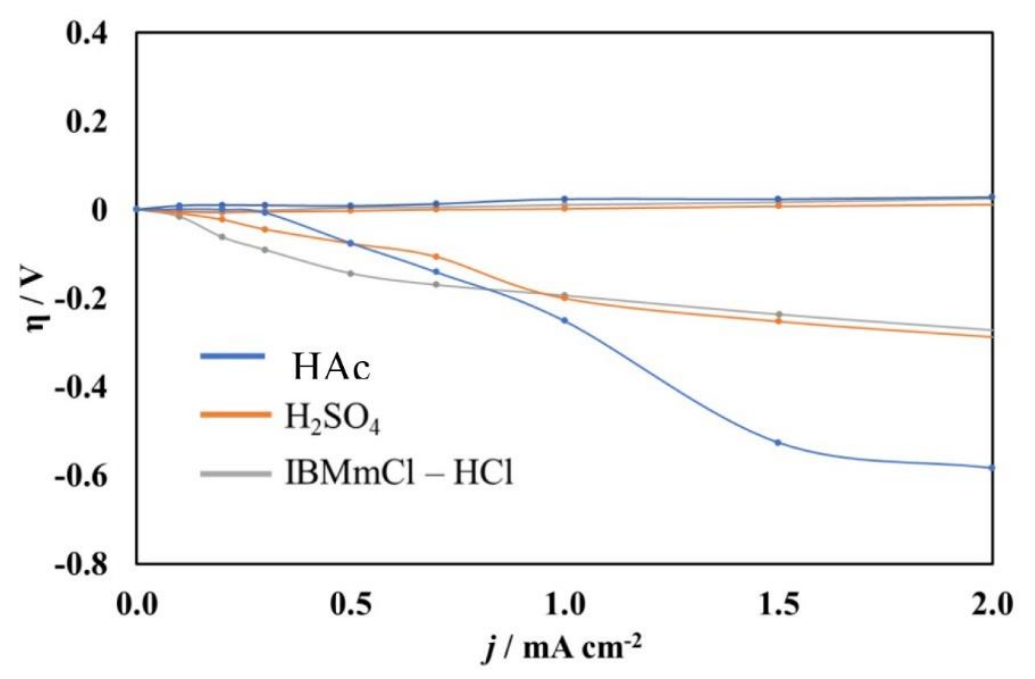

Figure 4 Overpotential ( $\eta$ ) vs. current density (j) curves for the oxidation of HQS and reduction of $\mathrm{BQS}$ on a Pt-C electrode in $0.8 \mathrm{M} \mathrm{HQS}$ in $5.5 \mathrm{M} \mathrm{HAc}-2 \mathrm{M} \mathrm{LiCl}(\mathrm{HAc}), 15 \mathrm{mM}$ $\mathrm{H}_{2} \mathrm{SO}_{4}\left(\mathrm{H}_{2} \mathrm{SO}_{4}\right)$, and $10 \mathrm{~m} \mathrm{IBMmCl}-1.0 \mathrm{M} \mathrm{HCl}(\mathrm{IBMmCl}-\mathrm{HCl})$ at $25^{\circ} \mathrm{C}$.

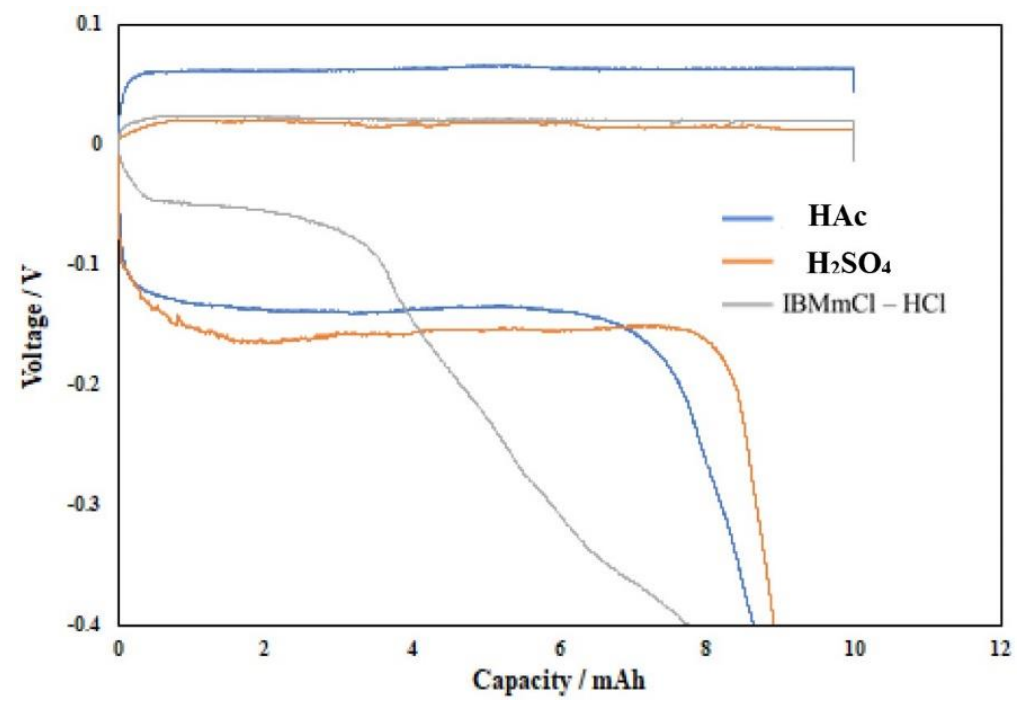

Figure 5 Electrode potential vs. capacity curves for HQS oxidation and $\mathrm{BQS}$ reduction on a Pt-C electrode in $0.8 \mathrm{M} \mathrm{HQS}$ in $5.5 \mathrm{M} \mathrm{HAc}-2 \mathrm{M} \mathrm{LiCl}(\mathrm{HAc}), 15 \mathrm{mM} \mathrm{H}_{2} \mathrm{SO}_{4}\left(\mathrm{H}_{2} \mathrm{SO}_{4}\right)$, and $10 \mathrm{~m} \mathrm{IBMmCl}-1.0 \mathrm{M} \mathrm{HCl}(\mathrm{IBMmCl}-\mathrm{HCl})$ at $25^{\circ} \mathrm{C}$.

The full cell performance of the lithium metal anode and the BQS/HQS redox couple cathode was also investigated. The Li/(LiFSI-2G)-50 vol\% DOL/LAGTP-epoxy-TiO $2 / 0.8 \mathrm{M}$ BQS in $5.5 \mathrm{M} \mathrm{HAc-2}$ $\mathrm{M} \mathrm{LiCl}$ aqueous solution/Pt-C cell was tested at $25^{\circ} \mathrm{C}$. The OCV was $3.7 \mathrm{~V}$, which was slightly lower than that of $3.92 \mathrm{~V}$ estimated from the $\mathrm{BQS}$ reduction potential in $1 \mathrm{M} \mathrm{H}_{2} \mathrm{SO}_{4}$ reported in the literature [17]. The low OCV could be due to the high $\mathrm{pH}$ of the catholyte, the junction potential between LAGTP-epoxy- $\mathrm{TiO}_{2}$ and the aqueous catholyte and anode electrolyte, and low lithium-ion activity at the Li/anode electrolyte. The impedance profile of the full cell at $25{ }^{\circ} \mathrm{C}$ is shown in Figure 6. The result showed two semicircles; one in the high-frequency range of $1 \mathrm{MHz}$ and $25 \mathrm{kHz}$ corresponds to the contribution of the grain boundary lithium-ion conduction in LAGTP-epoxy-TiO 2 and the other in a low-frequency range of $25 \mathrm{kHz}$ and $0.1 \mathrm{kHz}$ attributed to the contribution of 
charge transfer resistance [33]. The intercept of the high-frequency semicircle with the real axis at high frequency is the sum of the bulk resistance of LAGTP-epoxy-TiO 2 and the resistances of the buffer electrolyte and the catholyte. The ratio of these electrolyte resistances to the total cell resistance was around 0.5 . In this study, a $1 \mathrm{~mm}$ thick anode electrolyte and $0.2 \mathrm{~mm}$ thick LAGTPepoxy- $\mathrm{TiO}_{2}$ separator were used. The electrolyte resistance could be reduced by reducing the thicknesses of these electrolytes. Figure 7 shows the charge and discharge overpotential vs. current density curve for the Li/(LiFSI-2G)-50 vol\% DOL/LAGTP-epoxy-TiO $2 / 0.8 \mathrm{M} \mathrm{HQS-5.5} \mathrm{M} \mathrm{HAc-2}$ $\mathrm{M} \mathrm{LiCl}$ aqueous cell, where the cell was precharged at $0.5 \mathrm{mAcm}^{-2}$ for $50 \mathrm{~h}$ ( $20 \%$ of full charge). The charging overpotentials increased slightly with the increasing current density, while the discharging overpotential showed a significant increase. At $2 \mathrm{mAcm}^{-2}$, the round trip overpotential was $1.2 \mathrm{~V}$, corresponding to a $33 \%$ energy loss.

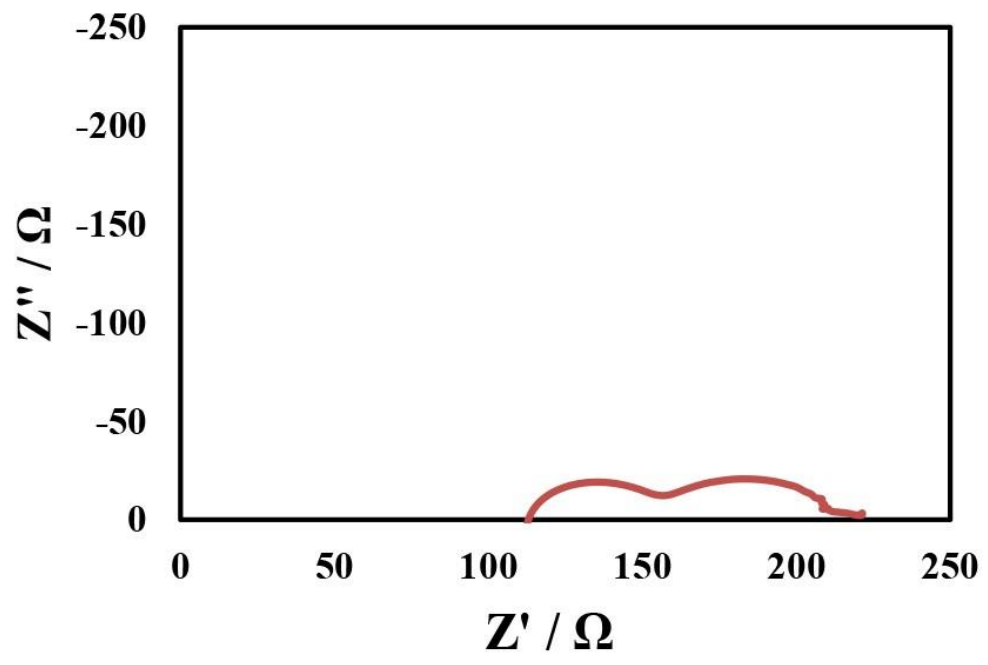

Figure 6 Impedance profile of Li/(LiFSI-2G)-50 vol\% DOL/LAGTP-epoxy-TiO $2 / 0.8 \mathrm{M} \mathrm{HQS}$ $5.5 \mathrm{M} \mathrm{HAc}-2 \mathrm{M} \mathrm{LiCl}$ aqueous solution/Pt-C cell at $25^{\circ} \mathrm{C}$.

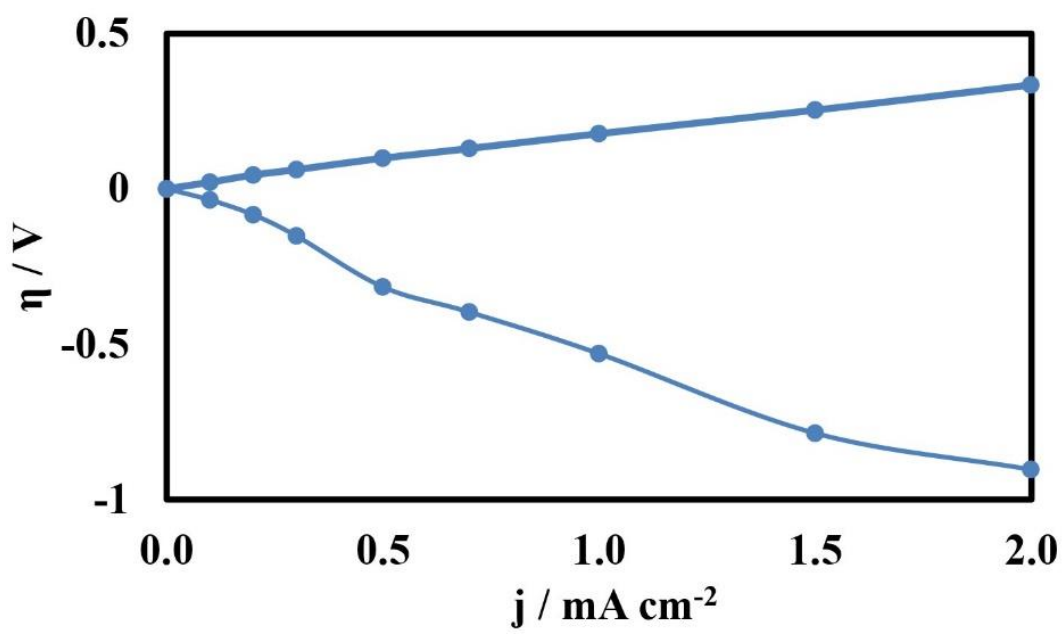

Figure 7 Overpotential ( $\eta$ ) vs. current density (j) curves for Li/(LiFSI-2G)-50 vol\% DOL/LAGTP-epoxy-TiO $2 / 0.8 \mathrm{M} \mathrm{HQS}-5.5 \mathrm{M} \mathrm{HAc}-2 \mathrm{M} \mathrm{LiCl}$ aqueous solution/Pt-C cell at $25^{\circ} \mathrm{C}$. 
The cycling performance of the Li/(LiFSI-2G)-50 vol\% DOL/LAGTP-epoxy-TiO $2 / 0.8 \mathrm{M} \mathrm{HQS-5.5} \mathrm{M}$ $\mathrm{HAc}-2 \mathrm{M} \mathrm{LiCl}$ aqueous solution/Pt-C cell at $0.5 \mathrm{~mA} \mathrm{~cm}^{-2}$ for $1 \mathrm{~h}$ discharge, $1 \mathrm{~h}$ rest, and then $1 \mathrm{~h}$ charge cycle at $25{ }^{\circ} \mathrm{C}$ is shown in Figure 8. The round-trip overpotential was $0.4 \mathrm{~V}$, which corresponds to a $12 \%$ energy loss. The discharge voltages were slightly decreased with each cycle. The deep charge and discharge profiles at $0.5 \mathrm{mAcm}^{-2}$ are shown in Figure 9. The cut-off voltages for charge and discharge were $4.5 \mathrm{~V}$ and $2.5 \mathrm{~V}$, respectively, and the mass of the charged HQS was $0.189 \mathrm{~g}$ (65 $\mathrm{mAh}$ ). The observed charge and discharge capacities were 49.6 and $26.5 \mathrm{mAh}$, respectively, which corresponded to $76 \%$ and $41 \%$ utility of the active material in the catholyte, respectively. The potential plateau for the hydrogen evolution reaction was observed at around $2.2 \mathrm{~V}$. The calculated energy density of the proposed Li/HQSK cell was $358 \mathrm{Whkg}^{-1}$ based on the masses of $\mathrm{Li}, \mathrm{H}_{2} \mathrm{O}$, and $\mathrm{BQS}$ and $41 \%$ utilization of $\mathrm{BQS}$ with an operating voltage of $3.4 \mathrm{~V}$. The calculated energy density of the proposed new type aqueous lithium battery was comparable to that of the convention lithium-ion battery. The calculated specific energy density of the cell generally depends on the specific area capacity [34], and the cell performance of a solid active material such as $\mathrm{LiCoO}_{2}$ in the lithium-ion batteries depends on the thickness of the electrode [35]. However, the cell performance of a cell with a liquid catholyte shows no significant dependence on the specific area capacity, as reported in the literature [11]. Hence, the proposed Li/BQS battery with a liquid catholyte could provide high energy density at a high area capacity.

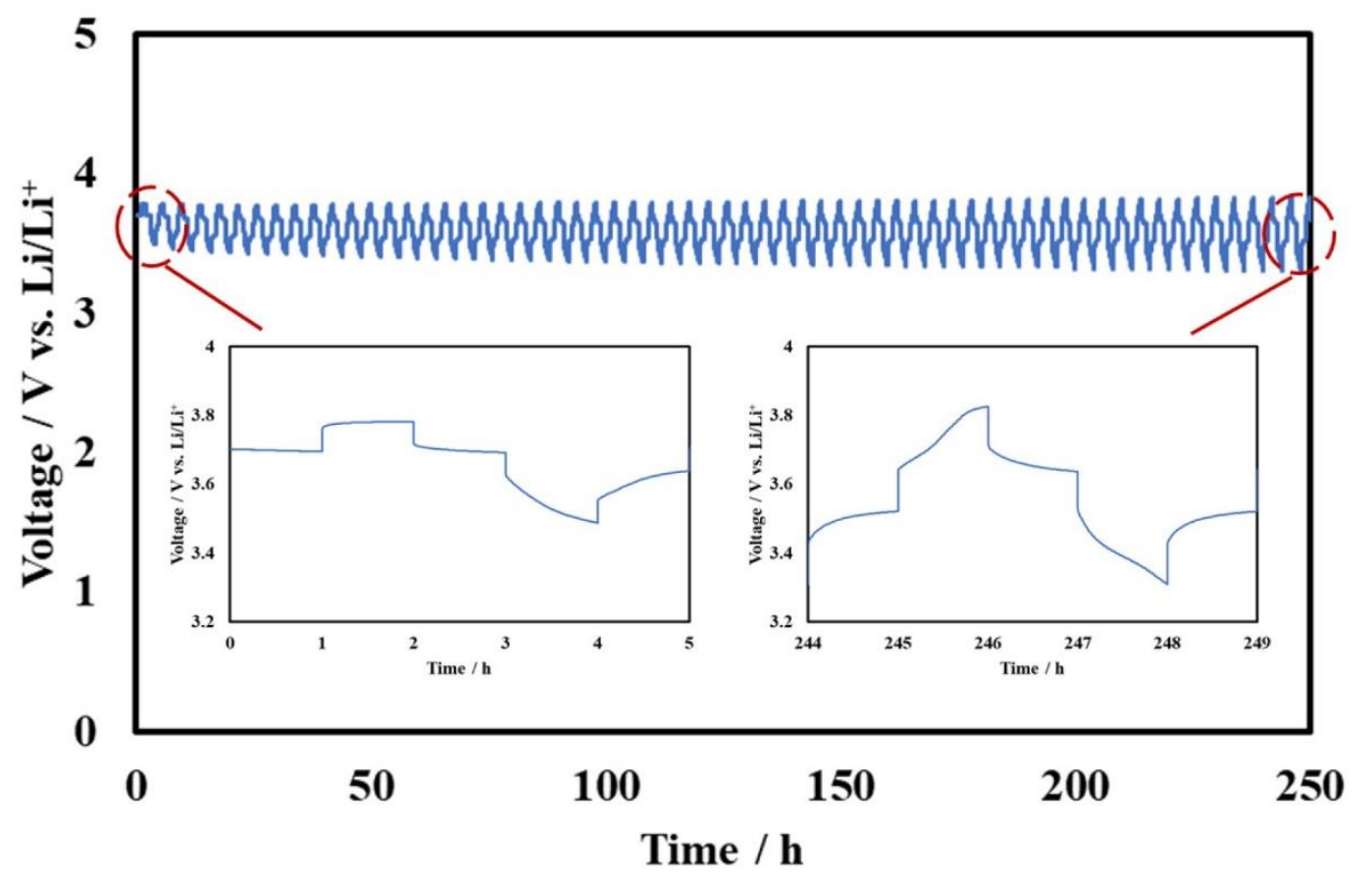

Figure 8 Cycling performance of the Li/(LiFSI-2G)-50 vol\%DOL/LAGTP-epoxy-TiO $/ 2 / 0.8 \mathrm{M}$ HQS-5.5 M HAC-2 M LiCl aqueous solution/Pt-C cell at $0.5 \mathrm{mAcm}^{-2}$ and $25^{\circ} \mathrm{C}$. 


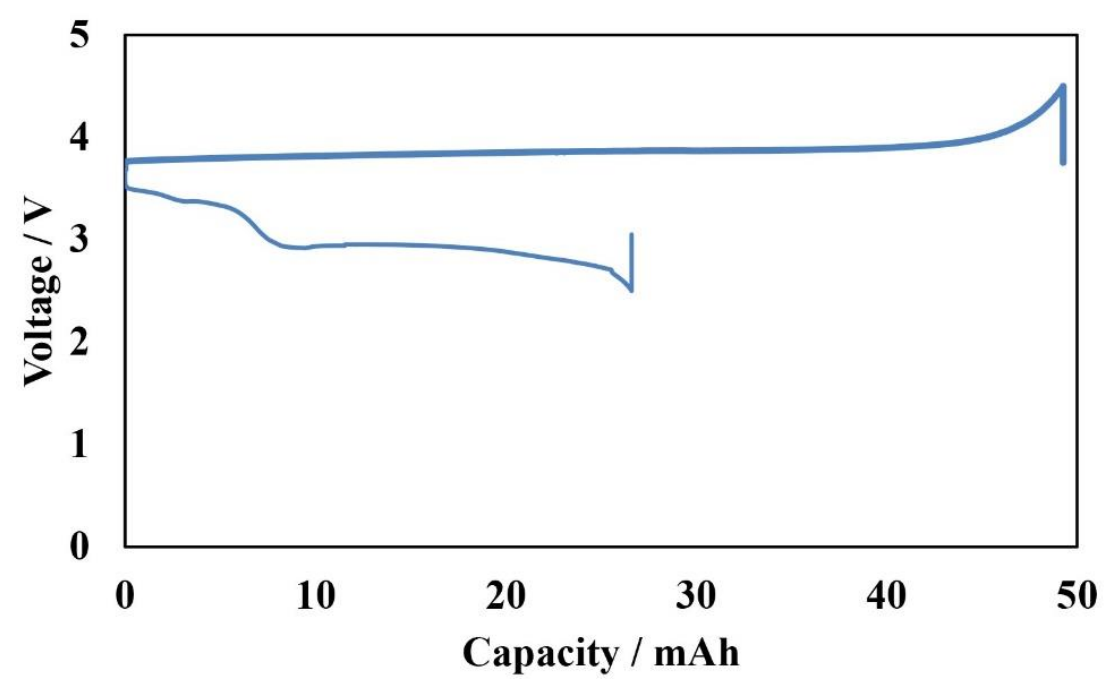

Figure 9 Charge and discharge curves of the Li/(LiFSI-2G)-50 vol\% DOL/LAGTP-epoxy$\mathrm{TiO}_{2} / 0.8 \mathrm{M} \mathrm{HQS}-5.5 \mathrm{M} \mathrm{HAc}-2 \mathrm{M} \mathrm{LiCl}$ aqueous solution/Pt-C cell at $0.5 \mathrm{mAcm}^{-2}$ and $25^{\circ} \mathrm{C}$.

\section{Conclusion}

The proposed novel aqueous lithium battery with a water-soluble and less expensive organic catholyte showed a higher theoretical specific energy density than conventional lithium-ion batteries. The cell performed well at $0.5 \mathrm{mAcm}^{-2}$ and $25^{\circ} \mathrm{C}$ and showed no significant degradation after 37 cycles. The battery with the aqueous catholyte could charge and discharge at a high specific area capacity, and the cost of the cathode active materials was lower than that of conventional lithium-ion batteries. Thus the proposed novel battery has a potential application for large-capacity batteries for electric vehicles and electric energy storage systems.

\section{Author Contributions}

HT prepared the solid electrolyte thin films, performed electrochemical measurements, and setup the full cell. KK prepared LAGTP fine powder. DM, S T, YT and OY supported and gave advice on each experimental work. NI managed the research direction and provided instructions and opportunities for discussions among all authors

\section{Funding}

This work was supported by JST Adaptable and Seamless Technology transfer Program through Target-driven R\&D (A-STEP) Grant Number JPMJTM120EP.

\section{Competing Interests}

The authors have declared that no competing interests exist.

\section{References}

1. Whittinham MS. Lithium batteries and cathode materials. Chem Rev. 2004; 104: 4271-4302.

2. Bruce PG, Freunberger SA, Hardwick $\amalg$, Tarascon JM. Li- $\mathrm{O}_{2}$ and Li-S batteries with high energy storage. Nat Mater. 2012; 11: 19-29. 
3. Visco SJ, Nimon E, Katz B, De Johne LC, Chu MY. Lithium metal aqueous batteries. Proceeding of 12th International Meeting on Lithium Batteries; 2004 June 27-July 2; Nara, Japan. Amsterdam: Elsevier.

4. Visco SJ, Nimon YS. Active metal/aqueous electrochemical cells and systems. U.S. Patent application; 2007; US7645543B2.

5. Imanishi N, Yamamoto O. Perspectives and challenges of rechargeable lithium-air batteries. Mater Today Adv. 2019; 4: 100031.

6. Li W, Dahn JR, Wainright DS. Rechargeable lithium batteries with aqueous electrolytes. Science. 1994; 264: 1115-1118.

7. Kim H, Hong J, Park KY, Kim H, Kim SW, Kang K. Aqueous rechargeable Li and Na ion batteries. Chem Rev. 2014; 114: 11788-11827.

8. Li H, Wang Y, Na H, Liu H, Zhou H. Rechargeable Ni-Li battery integrated aqueous/nonaqueous system. J Am Chem Soc. 2009; 131: 15098-15099.

9. Lu Y, Goodenough JB, Kim Y. Aqueous cathode for next-generation alkali-ion batteries. J Am Chem Soc. 2011; 133: 5756-5759.

10. Wang $X$, Hou Y, Zhu Y, Wu Y, Holze R. An aqueous rechargeable lithium battery using coated Li metal as anode. Sci Rep. 2013; 3: 1401.

11. Morita $Y$, Watanabe $S$, Zhang $P$, Wang $H$, Mori D, Matsuda $Y$, et al. High specific energy density aqueous lithium-metal chloride rechargeable batteries. J Electrochem Soc. 2017; 164: A1958.

12. Morita Y, Watanabe S, Mori D, Takeda Y, Yamamoto O, Imanishi N. High-energy-density rechargeable lithium-nickel chloride aqueous solution batteries. ACS Omega. 2018; 3: 55585562.

13. Watanabe S, Mori D, Taminato S, Matsuda Y, Yamamoto O, Takeda Y, et al. Aqueous lithium rechargeable battery with a Tin (II) chloride aqueous cathode and a water-stable lithium-ion conducting solid electrolyte. J Electrochem Soc. 2019; 166: A539.

14. Fei $H$, Liu Y, An Y, Xu X, Zeng G, Tian Y, et al. Stable all-solid-state potassium battery operating at room temperature with a composite polymer electrolyte and a sustainable organic cathode. J Power Sources. 2018; 399: 294-298.

15. Fieser LF. The tautomerism of hydroxy quinones. J Am Chem Soc. 1928; 50: 439-465.

16. Guin PS, Das S, Mandal PC. Electrochemical reduction of quinones in different media: A review. Int J Electrochem. 2011; 2011: 816202.

17. Bailey SI, Rritchie IM. A cyclic voltammetric study of the aqueous electrochemistry of some quinones. Electrochim Acta. 1985; 30: 3-12.

18. Yang B, Hoober-Burkhardt L, Wang F, Prakash GS, Narayanan SR. An inexpensive aqueous flow battery for large-scale electrical energy storage based on water-soluble organic redox couples. J Electrochem Soc. 2014: 161: A1371

19. Yang B, Hoober-Burkhardt L, Krishnamoorthy S, Murali A, Prakash GS, Narayanan SR. Highperformance aqueous organic flow battery with quinone-based redox couples at both electrodes. J Electrochem Soc. 2016; 163: A1442.

20. Hoober-Burkhardt L, Krishnamoorthy S, Yang B, Murali A, Nirmalchandar A, Prakash GS, et al. A New michael-reaction-resistant benzoquinone for aqueous organic redox flow batteries. J Electrochem Soc. 2017; 164: A600. 
21. Shimonishi $Y$, Zhang $T$, Johnson $P$, Imanishi N, Hirano A, Takeda $Y$, et al. A study on lithium/air secondary batteries-Stability of NASICON-type glass ceramic in acid solution. J Power Sources. 2010; 195: 6187-6191.

22. Wang $H$, Matsui $M$, Kuwata $H$, Sonoki $H$, Matsuda $Y$, Shang $X$, et al. A reversible dendrite-free high-areal-capacity lithium metal electrode. Nat Commun. 2017; 8: 15106.

23. Bai $F$, Shang $X$, Mori $D$, Taminato $S$, Matsumoto $M$, Watanabe $S$, et al. High lithium-ion conducting solid electrolyte thin film of $\mathrm{Li}_{1.4} \mathrm{Al}_{0.4} \mathrm{Ge}_{0.2} \mathrm{Ti}_{1.4}\left(\mathrm{PO}_{4}\right)_{3}-\mathrm{TiO}_{2}$ for aqueous lithium secondary batteries. Solid State Ion. 2019; 338: 127-133.

24. Kyono N, Bai F, Nemori H, Minami H, Mori D, Takeda $Y$, et al. Lithium-ion conducting solid electrolytes of $\mathrm{Li}_{1.4} \mathrm{Al}_{0.4} \mathrm{Ge}_{0.2} \mathrm{Ti}_{1.4}\left(\mathrm{PO}_{4}\right)_{3}$ and $\mathrm{MO}_{\mathbf{x}}(\mathrm{M}=\mathrm{Al}, \mathrm{Ti}$, and $\mathrm{Zr})$ composites. Solid State Ion. 2018; 324: 114-127.

25. Takahashi K, Johnson P, Imanishi N, Sammes N, Takeda Y, Yamamoto O. A water stable high lithium ion conducting $\mathrm{Li}_{1.4} \mathrm{Ti}_{1.6} \mathrm{Al}_{0.4}\left(\mathrm{PO}_{4}\right)_{3}$-epoxy resin hybrid sheet. J Electrochem Soc. 2012; 159: A1065.

26. Hasegawa S, Imanishi N, Zhang T, Xie J, Hirano A, Takeda Y, et al. Study on lithium/air secondary batteries-Stability of NASICON-type lithium ion conducting glass-ceramics with water. J Power Sources. 2009; 189: 371-377.

27. Shimonishi $Y$, Zhang T, Imanishi N, Im D, Lee DJ, Hirano A, et al. A study on lithium/air secondary batteries - Stability of the NASICON-type lithium ion conducting solid electrolyte in alkaline aqueous solutions. J Power Sources. 2011; 196: 5128-5132.

28. Zhang T, Imanishi N, Takeda Y, Yamamoto O. Aqueous lithium/air rechargeable batteries. Chem Lett. 2011; 40: 668-673.

29. Ye R, Henkensmeier D, Chen R. Imidazolium cation enabled reversibility of a hydroquinone derivative for designing aqueous redox electrolytes. Sustain Energy Fuel. 2020; 4: 2998-3005.

30. Quan M, Sanchez D, Wasylkiw MF, Smith DK. Voltammetry of quinones in unbuffered aqueous solution: Reassessing the roles of proton transfer and hydrogen bonding in the aqueous electrochemistry of quinones. J Am Chem Soc. 2007; 129: 12847-12856.

31. Wu G, Swaidan R, Cui G. Electrooxidations of ethanol, acetaldehyde and acetic acid using PtRuSn/C catalysts prepared by modified alcohol-reduction process. J Power Sources. 2007; 172: $180-188$.

32. Siné $G$, Smida $D$, Limat $M$, Foti G, Comninellis C. Microemulsion synthesized Pt/Ru/Sn nanoparticles on BDD for alcohol electro-oxidation. J Electrochem Soc. 2007; 154: B170.

33. Bruce PG, West AR. Ionic conductivity of LISICON solid solutions, $\mathrm{Li}_{2+2 \times} Z_{n_{1-x}} \mathrm{GeO}_{4}$. J Solid State Chem. 1982; 44: 354-365.

34. Park MS, Ma SB, Lee DJ, Im D, Doo SG, Yamamoto O. A highly reversible lithium metal anode. Sci Rep. 2014; 4: 3815-3822.

35. Zheng H, Li J, Song X, Liu G, Battaglia VS. A comprehensive understanding of electrode thickness effects on the electrochemical performances of Li-ion battery cathodes. Electrochim Acta. 2012; 71: 258-265. 
JEPT 2021; 3(1), doi:10.21926/jept.2101010

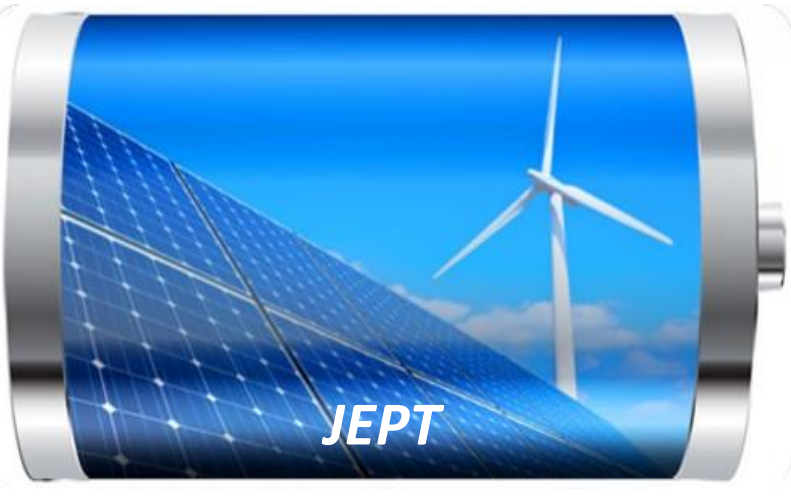

Enjoy JEPT by:

1. Submitting a manuscript

2. Joining in volunteer reviewer bank

3. Joining Editorial Board

4. Guest editing a special issue

For more details, please visit:

http://www.lidsen.com/journal/jept 